\title{
Educational Mismatch between Graduates Possessed Skills and Market Demands in Pakistan
}

\author{
Muhammad Uzair-ul-Hassan ${ }^{1} \&$ Zahida Noreen ${ }^{1}$ \\ ${ }^{1}$ Department of Education, University of Sargodha, Pakistan \\ Correspondence: Muhammad Uzair-ul-Hassan, Department of Education, University of Sargodha, Pakistan. \\ E-mail: uhassan74@gmail.com
}

Received: September 21, 2013

Accepted: October 21, 2013 Online Published: October 29, 2013

doi:10.5539/ies.v6n11p122

URL: http://dx.doi.org/10.5539/ies.v6n11p122

\begin{abstract}
Educational mismatch in skills that graduates possess and market requires creates barriers for organizations as well as for job seekers. The study was conducted to find out the educational mismatch between graduates possessed skills and market demands. Convenient sampling was carried out and data were collected from 200 graduates of economics studying in universities in Punjab, Pakistan. Further, 32 employers of various organizations at Sargodha, Pakistan were also included from whom requisite skills in market was investigated. The statistical techniques t-test and percentage of responses were employed to analyze the data. Analysis shows that there exists difference between graduates possessed skills and employers demand. There also exists difference between achievement level of students and achievement level demanded by employers. Further, it was found that there was a significant difference between skills possessed by male and female, and between high and low achiever graduates in economics. Also significant difference exists in skills graduates possess who are in jobs either full-time or part-time. The study concludes that communication, strategic thinking, abstraction and research skills are the main causes of educational mismatch.
\end{abstract}

Keywords: educational mismatch, market, graduates possessed skills

\section{Background}

The economic role of human capital, particularly education has long been documented by economists and policy makers (Becker, 1964). According to some observers view, educational system is an effective vehicle for producing the skills required to maintain growth in the economy. The versatile impact of education on every aspect of human existence makes it a vital area for policy framework especially for developing countries. Developing countries where majority of world's population resides need to maximize productivity and capabilities of the advanced human capital.

Due to the declining returns to education and the increasing gap between required and provided skills, knowledge and abilities there arises educational mismatch. Educational mismatch is defined as the lack of coherence between required and offered educational level for a given job (Allen \& Velden, 2001). The incidence of educational mismatch is one of the elements used to estimate the effectiveness of qualifications.

There exists much literature on the problem of educational mismatch but study acquires more importance if the study population is composed of graduates. This is because of the fact that as the students acquire high qualification, the longer duration of the education increases their expectations which are not always satisfied by the opportunities offered by the labor market.

Educational mismatch arises in the form of over education (i.e. workers have more education than is required for their jobs) or under education (i.e. workers have less education than is required for their jobs). Vertical mismatch of education (mismatch of level of education and job) is not the only form of educational mismatch. Another important form of mismatch is horizontal mismatch (i.e. mismatch of field of study and job).

Over-education/over-qualification is a relative phenomenon. A person over-educated/over-qualified in one job may not be in another job. Overeducated workers are defined as those whose educational attainments exceed to the requirements of education in a particular occupation.

The match between required and provided skills plays a crucial role for economic growth. The alignment between skill demand and supply in the labor market supports firms in filling up vacant positions and cuts the 
costs of process re-engineering. Matched employees benefit from higher returns to their investment in education and training and enjoy higher satisfaction levels. In addition, matching in the labor market signals the success of public policies in support of education and vocational systems. Skills demanded by the employers can be core skills (e.g. knowledge application) as well as the supplementary skills (e.g. IT skills, communication etc). There may be skill surplus and skills deficit. Educational mismatch exists in both conditions.

Educational mismatch can be studied in variety of fields and disciplines. This is particularly for graduates in economics, since this degree is considered 'Strong' because it offers a wide choice of alternatives and has high external effectiveness. The subject has a broad focus but still graduates in economics are facing the difficulties in getting the jobs that are matching with their qualification. Most of the employers reports that graduates in economics do not possess good communication skills.

Researchers and other professionals have been interested in the relationship between graduates in economics and educational mismatch. There is also a body of research that has identified over education, gender bias, and family background and under education as significant causes of educational mismatch. The main focus of this study is the identification of the major causes of educational mismatch.

Educational mismatch is a phenomenon that can be studied in different dimensions. Over education is considered one basic determinant of educational mismatch. In earlier studies educational mismatch is perceived as temporary phenomena (Quintano, Castellano, \& Agostino, 2008). The empirical text in various developed regions has mainly focused the over-education' which range from 10 percent to 40 percent in various developed countries Over-education implies underutilization of skills and unemployment for the least qualified. Robset (1995) notes, "those who attend the lowest quality schools may be overeducated throughout their career. Those who attend a better school may be able to work their way upward during their career. Thus over-education can be a temporary or permanent condition."

Gender inequality is a specific form of inequality because it does not arise from existing difference in economic contribution but from existing social perceptions and norms. Women have been in a subordinate position throughout history. The existence of gender wage differentials has been widely documented in most developed countries. The study of wage differentials by levels of education is often applied to control for individual heterogeneity. The gender wage gap is found to be higher at the bottom of the distribution for individuals with lower levels of schooling; the gender gap appears to be greater at the top of the distribution for individuals with higher education (Lopez \& Murillo, 2009).

Returns to years of educational mismatch are in favor of men. Returns to years of schooling in excess of those required by a job tend to be half those for required years of schooling, with men obtaining higher returns to years of surplus education than women do. On the other hand, returns to years of under schooling tend to be negative, with women suffering greater penalties for each year of under education than their male counterparts. Thus, although returns to years of required education are higher for women, it is found that women suffer to a greater extent the earnings losses associated with educational mismatch.

Family background may impact the individuals' choices in many ways. Family background includes different variables e.g. education level of father, education level of mother, socio-economic status, region of living (Corak, Lipps, \& Zhao, 2003). Cultural background is extremely relevant in this process even because better educated parents may value their children's education more than the others (Lopez \& Murillo, 2009). On the other hand, parents may increase individual employment opportunities through informal networks (Mueller \& Finnie, 2008).

Education characteristics (e.g. attainment level) are among the main determinants of the education-job match. It examines four concepts: 1) Field of study; 2) Level of study; 3) Grades; and 4) Recent work/school experience. Good grades during school also affect the education-job match (Chiswic, 2009). This might be attributable to the fact that employers view this as an indicator of ability to excel at the subject related skills (Adams \& Smart, 2008). Research evidences show that the better grades obtained during education increases the match.

There is an evidence on the fact that part-time study student have less probability of unemployment and educational mismatch. But with the passage of time this gap narrow down. This is may be due to the reason that part-time students have high confidence level and are well informed about the job opportunities. Part-time students have high salary as compared to full-time students because they are aware about job requirements (Wilkinson, 2011). So they usually are less affected by educational mismatch.

Mismatches are most often looked by skills. The match between required and provided skills plays a crucial role for economic growth. Allen and Velden (2001) identify four different types of skill mismatch, respectively named as wrong skills (characterized by the simultaneous presence of skill deficit and over skilling). Skill 
shortage (skill deficit and no over skilling), Skill match (no skill deficit and no skill under utilization) and skill surplus (no skill deficit and over skilling).

Given the risks posed to globalised economic systems by skill shortage in the labor force, under education and under skilling deserve as much attention as the more explored concepts of over education and over skilling.

The phenomenon of skill mismatch is present on both sides; demand side and supply side. A separate and perhaps more substantive reason for limited understandings of mismatch is the failure to consider more carefully both the role of the supply and the demand sides of the labor market in generating mismatch. Theory suggests that there are a variety of pervasive and complex mechanisms that generate mismatch which require careful consideration (Desjardins \& Rubenson, 2011).

Approaches that emphasize the supply side of the labor market in modeling labor market functioning as it pertains to skills, skill use and skill development, tend to portray skill mismatch as a phenomenon driven by supply side conditions. From this perspective, mismatch tends to be attributed to the inadequacies of the education and training system. In a situation of over education, for example, the response is that education and training systems should aim to reduce the number of qualifications they produce. Overall, education and training systems should ensure quality and be made to be more responsive to the needs of the labor market, and to offer more guidance at critical transition points to minimize mismatch.

In contrast, approaches that emphasize the demand side of the labor market tend to portray skill mismatch as a phenomenon driven by demand side conditions. From this perspective, mismatch tends to be attributed to the inadequacies of labor market practices and of employers to identify and correct for mismatch, either via the provision of additional education, or in terms of adjusting work and organizational practices in ways that optimize skill use and skill gain, and avoids skill loss over time.

According to assignment theory, the allocation is optimal when workers are allocated top-down according to their skills, whereby the most competent worker is assigned to the most complex job and the least competent worker is assigned to the simplest job. The incidence of educational mismatches can thus be explained by differences in the shares of complex jobs and skilled workers.

Studies show that employers perceive economics graduates are not particularly strong in skills because of lack of experience (Doherty, Street, \& Webber, 2007). There is, therefore, some evidence of a mismatch between employers' requirements and the skills and knowledge possessed by students. There is disparity between required and current skills of graduates of economics (Doherty et al., 2007).

Skill mismatch and skill deficit can be perceived as the result of continued technical changes in the economy (Desjardins \& Rubenson, 2011). Computerization may reduce the demand for medium skilled workers, namely by serving as a substitute for medium level job tasks, for example, routine cognitive tasks (Malo, 2005). Others have earlier maintained that the introduction of new technologies requires more skilled workers and that the two are complements (Malo, 2005).

The primary purpose of higher education is to prepare students for the world of work. Graduates need to be given opportunities to develop generic attributes besides disciplinary knowledge. Generic attributes include communication skills, problem-solving skills, computer literacy, information literacy, ability and willingness to learn, and teamwork. Previous research conducted on graduate employment addressed generic competencies as skills, abilities and attributes that complement the field of specialization of employees for work performance (Malo, 2005). It was noted that employers prefer workers who had generic competencies like interpersonal skills, and leadership skills, teamwork, oral and written skills (Lee, 2012). It was again reported that there were plenty of jobs but many graduates cannot fit into the positions because they lacked the necessary skills (language and communication skills) that their prospective employers were looking for. The integration of creativity into business education aids students in preparing for the creative workplace environments that are becoming more common as organizations seek to develop creative competencies as one of their few sustainable competitive advantages in today's marketplace (Allen \& Velden, 2001).

There are different types of skills in which there exists deficit or surplus and that contributes to the educational mismatch. Many employers cited lack of necessary communication skills, poor command of English and lack of confidence during interviews had led to increasing number of unemployed graduates. Furthermore, computer literacy or the knowledge of information technology is supplementary skill required by employers (Sgobbi, 2011). According to Doherty et al. (2007), students of economics who have deficit in that particular skill have high probability of educational mismatch than students who have competency in applying their knowledge to the real world phenomena. 
According to Groot and Maasen (2000) economists must do what they are trained to do. Reason behind that deficit in research skills is the lack of incentives for conducting research and lack of faculty members to train students as a researcher (Aleem, 2004). Only the attendance of students in their academics cannot increase their chances of job, they must have skills that can help them in their careers. A considerable amount of career-related skills are developed in non-instructional settings (Heckman, 2007). This connection between education and employment is exemplified in today's depressed job market, where there are more applicants for fewer jobs. High grade point averages are still necessary in job candidates, though high grades alone are not enough to secure a job (Chiswic \& Miller, 2009).

Youth unemployment is rising because of changing demands of labor market (Mohring, 2002). This is due to the failure of education to prepare youth for the job market (Mohring, 2002). There exists skill mismatch this is because there is no culture of entrepreneurship in Pakistan and other countries that are facing the problem of educational mismatch (Aleem, 2004). The skill of entrepreneurship is needed for the development in social and economic environment. Graduates are facing deficit in that particular skill because there is lack of public policy. For that purpose improve educational level of young people with innovative training schemes. For that institutions should offer special training programs for entrepreneurs.

In Pakistan, there is significant rise in the average level of education, but over time, more and more workers incapable to use their educational background on the job. Two decades ago, it was judgment that supply of labor meeting the demand of labor. However in the current decade, it is argued that supply of labor may have outstripped the demand of labor in some professions and high qualified peoples taking positions of low qualified peoples, therefore the skills of some highly educated group may be underutilized.

The return to education has a declining trend in Pakistan, implies that the country has failed to produce high demand for education (Qayyum, 2007). Despite rising labor force, the unemployment rates also remained high $5.6 \%$ during 2001-10 periods (ESP, 2010-11), suggesting that employment generation has not kept pace with the labor force. Meanwhile, quality of jobs and the access to modest earning opportunities still remained an issue. The educated unemployment (Graduation and above) has increased during FY00 and FY06. With rising employment participation, the labor market imperfections and imbalances have also rose; with rising job search periods, rising share of informal sector, lower productivity and high risk of vulnerability especially for youth and female (GoP, 2008). The market is skewed toward influential peoples where job opportunities are predominately reference-oriented rather than skill oriented.

In Pakistan educational mismatch is increasing day by day. Every year Universities in Pakistan are producing thousands graduates but most of them remained unemployed due to their over qualification or under qualification. There is an information gap that exists between labor market and graduates. College and university graduates are unaware about the job opportunities. According to Higher Education Commission (2012) in 2009 the number of higher education institutions was 127 and these institutions produced 496207 graduates and participation rate was $33.0 \%$ which shows that most of our labor markets are unable to absorb the fresh graduates.

There exists number of studies that have analyzed the phenomena of educational mismatch throughout the world. This has been a phenomenon of interest among Pakistani researchers and some studies have been carried out on the problem of educational mismatch in terms of over education and wage differentials. But in Pakistan no study exists on the phenomena of educational mismatch in terms of skills. The present study deals with the problem of educational mismatch in terms of skills and contributes to the recent literature.

The purpose of the study is to investigate educational mismatch related to skills faced by graduates in economics and the existing market demands.

Objectives of the study are to explore market demands for economic graduates and based on market demands, to explore educational mismatch in terms of skills of students. Further, to identify causes of the educational mismatch also forms the part.

The research questions developed for the study are as:

Does educational mismatch exist in skills between economics graduates and that of market demands? If exists, why does it exist?

Is there significant difference exist between skills possessed by males and females economics graduates.

Is there significant difference exist between skills possessed by high achievers and low achievers in economics. 
Is there significant difference exist between skills possessed by part time and full time economics graduates.

Is there significant difference exist between perception of students and employers about skills possession?

Is there significant difference between percentage of marks demanded by employers and percentage of marks possessed by students?

\section{Population, Sample \& Sampling}

All the graduates in economics of private and public colleges and universities were the target population of the study. Due to the time constraint students studying in department of economics of only one public sector university in Punjab, Pakistan were selected as the accessible population of the study. Similarly, employers were selected from only one district of Punjab, Pakistan.

Out of all the students studying in department of economics, 200 students studying at BS level were selected as the sample who believed to be the true representative of the given population and also had the characteristics relevant to the research problem. Furthermore, sample was categorized into full time and part time students, male and female students, high achievers and low achievers. So that 133 full time and 67 part time students, 105 female students and 95 male students, 105 high achievers and 95 low achievers were selected for the data collection. Out of all the employers working in Sargodha city 32 employers were selected as the sample of the study who believed to be the true representative of all the employers. Due to time constraint and limited availability of the participants of the study non-random convenient sampling was used.

Two questionnaires were used for collecting data. One questionnaire was used to collect data from students and the other to collect data from the employers. As per nature of the problem, questionnaire survey was used. A sample of 200 students was surveyed through questionnaire. On the other side sample of 32 employers was also surveyed through questionnaire. This study involved cross-sectional survey design because data was collected from the students of department of economics and employers at the same point in time. The nature of the study was quantitative form and it was survey type study. Two questionnaires were used for the collection of the data. Students studying in the final semester at BS level in department of economics were provided the questionnaire to tick the appropriate option. Likewise employers were also provided the questionnaire to tick the appropriate option on a rating scale using five different columns. Weights (ranging from 1 to 5 i.e. 1 - not at all, 2- to some extent, 3- to an adequate extent, 4- to a high extent and 5- to a very high extent) were assigned.

\section{Data Analysis}

Data were analyzed through the SPSS. Independent sample t-test and percentage of responses of employers and students were used to test the hypotheses and analyze the data.

Table 1. Students' percentage of marks and percentage of marks demanded by employers

\begin{tabular}{lll}
\hline Percentage of marks & Students' achievement level & Achievement level demanded by employers \\
\hline above 40 & 0.5 & 3.3 \\
above 50 & 3.5 & 20.0 \\
above 60 & 43.5 & 60.0 \\
above 70 & 52.5 & 16.7 \\
\hline
\end{tabular}

Table 1 shows students' achievement level and achievement level demanded by employers for job. Achievement level of most of the students is above $70 \%$ and the most demanded achievement level by employers is above $60 \%$. Results show that achievement level of students is more than the achievement level demanded by employers. 
Table 2. Skills possessed by students and skills possessed by students according to employers

\begin{tabular}{lll}
\hline Indicators of skills & $\begin{array}{l}\text { Students' } \\
\text { perception }\end{array}$ & $\begin{array}{l}\text { Employers' } \\
\text { perception }\end{array}$ \\
\hline Communication skills & 52.7 & 55.3 \\
Written communication & 59.9 & 59.3 \\
skill to think strategically & 59.6 & 56.0 \\
Abstraction & 57.3 & 54.0 \\
Skill to use diagrams & 66.0 & 56.0 \\
Application of economics knowledge & 67.0 & 53.3 \\
skill to deal & 63.8 & 60.7 \\
Speech skills & 58.6 & 56.7 \\
Problem solving skills & 58.2 & 55.0 \\
skill to be sensitive to social/cultural/political issues & 58.8 & 57.9 \\
Model construction skills & 58.6 & 56.6 \\
Debating skills & 56.3 & 70.7 \\
research skills & 57.3 & 53.3 \\
Team work skills & 61.1 & 67.9 \\
Resource identification skill & 59.7 & 56.6 \\
skill to use IT & 62.5 & 70.0 \\
Skills to use quantitative data & 60.6 & 65.4 \\
Application skills & 67.5 & 61.3 \\
\hline
\end{tabular}

Table 2 shows students' perception about skill possessed by students and employer' perception about skills possessed by students of economics. According to student, communication, written communication, strategic thinking, abstraction, debating and research are deficient areas in their skills. According to employers, students are deficient in communication, strategic thinking, abstraction, dealing, problem solving, model construction and research skills. Results show that communication, strategic thinking, abstraction and research are deficient area in students' skill possession.

Table 3. Skills possessed by males and skills possessed by females

\begin{tabular}{llllllll}
\hline Serial \# & dependent variable & gender & $\mathrm{N}$ & Mean & Standard deviation & $\mathrm{t}$ & Sig.(2-tailed) \\
\hline 1 & Skills possession & male & 95 & 54.54 & 11.48 & .319 & .750 \\
2 & & female & 105 & 54.02 & 11.46 & & \\
\hline
\end{tabular}

The independent sample $t$ test as shown in the table 4.95 shows that there is no significant difference in skills possessed by male and female students of economics ( $\mathrm{t}=0.319$, Sig. $=0.750$, Mean $_{\text {Male }}=54.54$, Mean $\left._{\text {Female }}=54.02\right)$. Female students of economics have equal skills as male economics students have.

Table 4. Skills possessed by high achievers and skills possessed by low achievers

\begin{tabular}{|c|c|c|c|c|c|c|c|}
\hline Serial \# & dependent variable & achievement & $\mathrm{N}$ & Mean & Standard deviation & $\mathrm{t}$ & Sig.(2-tailed) \\
\hline 1 & Skills & Low achievers & 95 & 52.08 & 11.23 & -2.61 & .010 \\
\hline 2 & & High achievers & 105 & 56.25 & 11.32 & & \\
\hline
\end{tabular}


The independent sample $t$ test as shown in the table 4.98 shows that there is significant difference in skills possessed by high achievers and low achievers $\left(\mathrm{t}=-2.61\right.$, Sig. $=0.010$, Mean ${ }_{\text {Low }}$ achievers $=52.08$, Mean High achievers $=56.25)$. High achievers possess more skills as compared to low achievers.

Table 5. Skills possessed by full time students and Skills possessed by part time students

\begin{tabular}{llllllll}
\hline Serial \# & dependent variable & Situation & $\mathrm{N}$ & Mean & Standard deviation & $\mathrm{t}$ & Sig.(2-tailed) \\
\hline 1 & Skills & Full time & 133 & 54.27 & 11.90 & -0.008 & 0.994 \\
2 & & Part time & 67 & 54.28 & 10.56 & & \\
\hline
\end{tabular}

The independent sample $t$ test as shown in the table 4.100 shows that there is no significant difference in skills possessed by full time students and part time students $\left(\mathrm{t}=-0.008\right.$, Sig. $=0.994$, Mean Full time students $=54.27$, Mean ${ }_{\text {Part }}$ time students $=54.28)$. Part time and full time students have equal skills possession.

\section{Findings}

Analyses reveal following findings:

1) The significant difference between skills possessed by males and skills possessed by female students of economics was found to be -0.319 at 0.05 . So, there is no significant difference between skills possessed by males i.e. 54.02 and skills possessed by females i.e. 54.54 .

2) The significant difference between skills possessed by high achievers and skills possessed by low achievers of economics was found to be -2.61 at 0.05 . There is no significant difference between skills possessed by high achievers and skills possessed by low achievers. The mean of high achievers' knowledge 56.25 is greater than mean of low achievers i.e. 52.08.

3) The significant difference between skills possessed by full time students and skills possessed by part time students of economics was found to be -0.008 at 0.05 significance levels of confidence. So, there is no significant difference between skills possessed by full-time and part-time students. There is no significant difference between skills possessed by full-time i.e. 54.27 students and part-time i.e. 54.28.

\section{Conclusion}

The study concludes that communication, strategic thinking, abstraction and research are deficient areas in students' skill possession that can cause skill mismatch and educational mismatch. Further, achievement level of graduates is more than the achievement level required for a job. The female students and male students possess equal levels of skills. So males and females students have equal probability of educational mismatch as far as skills are concerned. Achievement level of students is more than the achievement level demanded by employers. This increases the probability of students with high achievement level and also causes educational mismatch. The study also indicates that part-time and full-time students have no difference in skills, hence, the situation of the student (part time/full time) doesn't cause educational mismatch. Most of the results of study are similar to those searched by many others economists and educationists like Doherty, Street and Webber, 2007; Allen and van vel den, 2001; Lopez and Murrilo, 2009; Groot and Massen, 2000. But some results of the study like no difference between skill possession by full time and part time students are quite different to those searched by many other researcher like Wikinson, 2011; Adams and Smart, 2008. Probably, this is because of small sample of part time students used in the study. Another reason for no difference in skills possession between part time and full time students, probably the nature of job of part time students is different from field of economics. Further, skills of the students who are working in organizations are different from the skills of students of economics. Research in the area of skills mismatch and educational mismatch will be of limited theoretical and applied value unless a holistic perspective is considered.

\section{References}

Adams, \& Smart. (2008). Education and Lifelong Learning. The Scottish Government.

Aleem. (2004). The Determinants of Institutional Quality. More on the Debate, CREDIT Research Paper. Retrieved April 26, 2012, from http://www.nottingham.ac.uk/economics/credit/

Allen, J., \& Valden, V. V. (2001). Educational mismatches versus skill mismatches: Effect on wages, job satisfaction and on-the-job search. Oxford Economics Paper, 1(3), 434-452. Oxford University Press. http://dx.doi.org/10.1093/oep/53.3.434 
Becker, G. S. (1964). Human Capital: A Theoretical and Empirical Analysis with Special Reference to Education. New York, Columbia University Press.

Chiswic, B. R., \& Miller, P. W. (2009). Educational Mismatch: Are High-Skilled Immigrants Really Working at High-Skilled Jobs and the Price They Pay If They Aren't? Discussion Paper No. 4280.

Corak, M., Lipps, G., \& Zhao, J. (2003). Family income and participation in post-secondary education, Analytical Studies Branch research paper series.

Desjardins, R., \& Rubenson, R. (2011). An Analysis of Skill Mismatch Using Direct Measures of Skills. OECD Education Working Papers, No. 63, OECD Publishing. http://dx.doi.org/10.1787/5kg3nh9h52g5-en

Doherty, R. O., Street, D., \& Webber, C. (2007). The Skills and Knowledge of the Graduate Economist. University of the West of England, Bristol.

GoP. (2008b). Government of Pakistan. Pakistan. Employment Trends Youth, Ministry of Labour, Manpower and Overseas Pakistanis, Labor Market Information and Analysis Unit, Islamabad.

Groot, W., \& Maasen. (2000). Overeducation in the labor market: A Meta-Analysis. Economic of Education Review, 1(19), 149-158.

HEC. (2012). The Higher Education Commission of Pakistan, Islamabad. Retrieved from http://beta.hec.gov.pk/Pages/HECMain.aspx

Heckman, J. (2007). The Economics Technology and Neuroscience of Human Capability Formation, Working Paper No 13195 prepared for National Bureau Of Economic Research, Massachusetts.

Lopez, M. R., \& Murillo, I. P. (2009). Educational attainments, educational mismatch and gender wage differentials: An application to the Spanish case, FEDER.

Malo, M. A. (2005). Educational Mismatch and Labor Mobility of People with Disabilities: A Spanish Case. Blazquaz and Malo/Revista de Economia Laboral, 5(2), 31-55.

Mohring, J. (2002). Creating Opportunities for Young People in Berlin: Support for Self-Employment, OECD LEED Program.

Mueller, R., \& Finnie, R. (2008). The Effects of Family Income, Parental Education and Other Background Factors on Access to Post - Secondary Education in Canada, Canadian Education Project Qayyum. Growth Diagnostics in Pakistan, PIDE Working Paper 2006-07.

Quintano, C., Castellano, R., \& Agostino, A. D. (2008). Graduates in economics and educational mismatch: the case study of the University of Naples 'Parthenope'. Journal of Education and Work, 8(3), 249-271. http://dx.doi.org/10.1080/13639080802214118

Robest, J. (1995). College Quality and Overeducation. Economics of Education Review, 221-228.

Sgobbi, F. (2011). The skill match of young graduate employees: An empirical analysis based on REFLEX data. DEHEMS Conference, 22-23.

Wilkinson. (2011). The impact of higher education for part-time students, UK Commission for Employment and Skills.

\section{Copyrights}

Copyright for this article is retained by the author(s), with first publication rights granted to the journal.

This is an open-access article distributed under the terms and conditions of the Creative Commons Attribution license (http://creativecommons.org/licenses/by/3.0/). 